University of Massachusetts Amherst

ScholarWorks@UMass Amherst

\title{
China's Ancient Principles of Price Regulation through Market Participation: The Guanzi from a Comparative Perspective
}

Isabella Weber

Economics Department, University of Massachusetts Amherst

Follow this and additional works at: https://scholarworks.umass.edu/econ_workingpaper

Part of the Asian Studies Commons, Economic History Commons, Growth and Development Commons, and the Political Economy Commons

\section{Recommended Citation}

Weber, Isabella, "China's Ancient Principles of Price Regulation through Market Participation: The Guanzi from a Comparative Perspective" (2021). Economics Department Working Paper Series. 313.

https://doi.org/10.7275/wess-ma20

This Article is brought to you for free and open access by the Economics at ScholarWorks@UMass Amherst. It has been accepted for inclusion in Economics Department Working Paper Series by an authorized administrator of ScholarWorks@UMass Amherst. For more information, please contact scholarworks@library.umass.edu. 


\title{
China's Ancient Principles of Price Regulation through Market Participation: The Guanzi from a Comparative Perspective ${ }^{1}$
}

\author{
Isabella M. Weber
}

\begin{abstract}
The History of Economic Thought as a field has long taken it as a premise that so far as ancient economic thought is concerned, only the Greeks and Romans are worth studying. This paper introduces the Guanzi as a core text in ancient Chinese economic thought on price stabilization from a comparative perspective with ancient Greek contributions. The Guanzi presents a framework for the empirical analysis of market fluctuations and price movements and derives principles of economic governance from this analysis. In contrast Plato and Aristotle come to the question of price determination from the angle of moral philosophy. They foreground the right behaviour on the part of the individual not the structural features of the market. The Guanzi articulates the so-called "light-heavy" (轻重, qingzhong) principles, where heavy represents "important" or "essential" and light connotes "unimportant" or "inessential." It argues that essential subsistence goods and production inputs are always "heavy," while the relative importance of each commodity shifts with market fluctuations. It suggests that the markets are inherently unstable, if left to their own devises. The state should participate in the market of "heavy goods" in order to stabilize the economy as a whole.
\end{abstract}

Keywords: History of Economic Thought, China, price theory, economic policy

\section{Introduction}

"One generally accepted assumption of Western economists is that, so far as ancient economic theories are concerned, only the Greeks and Romans developed anything worthy of study ..." (Hu 2009, i). In the spirit of such a dismissive view of China's ancient history of economic ideas, it is common practice to simply ignore the contributions of Chinese thinkers to the evolution of political economy. ${ }^{2}$ Most standard textbooks in the field of the history of economic thought do not make any mention of Chinese texts. The common historiography still is the one reflected in Schumpeter's History of Economic Analysis (1954). Schumpeter

\footnotetext{
${ }^{1}$ This paper is forthcoming as a book chapter. Please cite as follows: Weber, Isabella M. (forthcoming). China's Ancient Principles of Price Regulation through Market Participation: The Guanzi from a Comparative Perspective. In: Schefold, Bertram and Iwo Amelung (Eds.), European and Chinese Histories of Economic Thought. Abingdon: Routledge, pp. 246-258).

${ }^{2}$ Hu's (2009) book A Concise History of Chinese Economic Thought, written in the 1960s and 1980s, remains by far the most comprehensive overview in English. Spengler (1964, p. 223) and Chang (1987, p. 481) observe that works on the history of Chinese economic thought outside China remain extremely scarce. Two recent volumes aimed at introducing key contributions of major Chinese historians of economic thought to an English-speaking readership suggest that this has not changed significantly in the past few decades (Lin, Peach \& Wang 2014; 2019). Chen Huan-Chang's (1911a; 1911b) $\mathrm{PhD}$ thesis has for a long time been "the only major attempt to describe Confucian principles in economic terms to have appeared in English" (Witzel, 2002, xiv), and even though it was positively reviewed by Keynes in The Economic Journal (1912), it was not followed up by work of similar depth. None of the major textbooks in the Concise History of Economic Thought contains a discussion of Chinese contributions.
} 
asserted that there was nothing worth studying between the ancient Romans and Greeks and the Italian Scholastics. In his words: "So far as our subject is concerned we may safely leap over 500 years" (1954, p. 70). One may add, inferring from Schumpeter's treatment of the ancient world, that in his view one may not only skip the Islamic contributions of thinkers of the stature of Ibn Khaldun who fall into Schumpeter's gap, but also safely ignore the ancient Chinese.

As a result of the attitude illustrated by Schumpeter's classic, historians of economic thought are rarely concerned with ancient Chinese contributions. A central inquiry in economic theorizing since ancient times is the question of price determination. On this as on many other core economic issues, China has a long history of theorizing in the statecraft tradition. One text stands out in particular: The Guanzi. It is a core text in ancient Chinese economic thought on price stabilization. As I develop in this chapter, the Guanzi's approach to price regulation is encapsulated in the so-called "light-heavy" (轻重, qingzhong) principles, where heavy represents "important," "essential," or "expensive," and light connotes "unimportant," "inessential," or "cheap." In contrast to the lineage from the ancient Greeks and Romans to the Scholastics foregrounded by Schumpeter, the Guanzi is not concerned with the morally "just price" and the ideal order of things. Instead, as I derive here, it analyzes the constantly changing forces that determine prices in the emerging market economy of its time. The Guanzi recommends the ruler of the state to study these empirical dynamics in order to manipulate them with the aim of enriching the state, creating wealth for the people and stabilizing prices.

In its pragmatic outlook and focus on statecraft, the Guanzi is very different from its Greek counterparts, from Plato's quest for a utopian state and Aristotle's insistence on the distinction between natural and artificial social forms. ${ }^{3}$ The Guanzi is not concerned with an ideal state but with a feasible form of governance. A distinction between natural and artificial remains of little relevance to the Guanzi since its aim is not to preserve a natural order but to channel the prevailing - or natural - forces so as to create wealth for the state. The questions pursued by Plato and Aristotle in their analysis of prices are normative: What price should be charged? What constitutes fraud? Why should greed and profit be condemned? They are concerned with the right price from the perspective of moral rules. In Roman legal thought this moral inquiry later develops into laws that prescribe severe punishments against overcharging in response to inflation, as for example in the Diocletian's Edict of Maximum Prices (301 A.D.). ${ }^{4}$ In contrast, we can think of the Guanzi as a very early form of positive economics that is less about how things ought to be but about how they tend to be. The Guanzi proposes principles of price determination in the market that take greed, pursuit of profit and fraud as given. These principles of price determination are meant to serve the state in stabilizing prices through commerce instead of through policing.

In the remainder of this chapter, I develop the Guanzi's principles of price determination and regulation in the context of the economic challenges at the time. In the conclusion, I return to the comparative reflections just outlined. To be sure, I am not arguing that the Guanzi is

\footnotetext{
${ }^{3}$ My interpretation of Aristotle and Platon in this chapter is based on Schefold (2008).

${ }^{4}$ See Baldwin (1959, p. 16) for a discussion of the place of the Diocletian's Edict in the lineage from Roman legal to Scholastic theories of the just price.
} 
representative of all of China's ancient tradition of economic thought. In fact, the basic logic of state market participation articulated in the Guanzi has been repeatedly and severely challenged from a moral and idealist viewpoint in major, reoccurring debates in China (Weber 2020; also see Chapter $\mathrm{xx}$ in this volume on the Salt and Iron Debate). What I propose here is that the Guanzi merits comparative study. This chapter can only be a beginning of a much larger task.

\section{The Guanzi's Conception of Price Regulation through the Market ${ }^{5}$}

\subsection{The Historical Context}

The Spring and Autumn (772-476 BCE) ${ }^{6}$ and mid-Warring States (475-221 BCE) periods, widely considered "China's golden age of culture" (Hu 2009, p.19), were an "unusual age ... when old orthodoxies had collapsed but new ones had not yet emerged" (Pines 2009, p. 220). It was "the age of the "Hundred Schools"” (Pines 2018). During the mid-Warring States Period, economic considerations became increasingly important for government theory, and economic growth emerged as a major concern in light of constant warfare (Milburn 2007, p. 19). In many ways, this period laid the foundation for Chinese philosophy and long-standing social, economic, and political practices. This is not to suggest that the period was followed by any form of stagnation or continuity. But it was a ground-breaking age for China's intellectual and institutional trajectory. Regarding economic questions, the writings collected in the so-called Guanzi (管子) ${ }^{7}$ are the most important of these ancient contributions. The Guanzi, one of the largest of the ancient Chinese texts (Rickett 1993, p. 244), is considered by some to be the "most representative ... of the emerging political economy of the Warring States era" (von Glahn 2016, p. 77).

Historical scholarship shows that the Guanzi was written by several anonymous authors, probably state planners and economic advisors (Chin 2014, p. 32; Hu 2009, p. 100). Irrespective of the precise date of its creation, which is subject to scholarly debate, ${ }^{8}$ it is important that the Guanzi was composed in the context of turbulent times after the collapse of the Western Zhou and before the Qin dynasty unified China into a single empire for the first time. Most parts of the Guanzi were written in the form of dialogues between Duke Huan (桓公, 685-643 BCE) of the state Qi and his advisor Guan Zhong (管仲, ca. 710-645 BCE) with the latter providing answers to the questions of the duke (Chin 2014, p. 33; von Glahn 2016, p. 77). Guan Zhong is recognized as "one of the most renowned and influential statesmen in ancient China" (Hu 2009, p. 100). He was not an author of the Guanzi. The authors of the Guanzi referred to Guan Zhong to express their vision of what they imagined to be his economic policies during the rise of the state Qi to a temporary hegemon in the Spring and Autumn Period (von Glahn 2016, p. 44; Hu 2009, p. 100; Rickett 1998, p. 341).

\footnotetext{
${ }^{5}$ This is an excerpt from my book How China Escaped Shock Therapy (see Weber 2021).

${ }^{6}$ This period was chronicled in the Spring and Autumn Annals, sometimes attributed to Confucius, which gives it its name. Although the authenticity of Confucius's authorship is subject to debate, his life coincides with the time of writing (Li 2013, p. 161).

${ }^{7}$ This chapter relies on the translation of the Guanzi by Rickett (1998) as well as on relevant secondary sources.

${ }^{8}$ Rickett (1998), in the comments of his translation of the Guanzi, discusses the dating of each section in detail. See also Chin (2014, pp. 32-3) and von Glahn (2016, pp. 77-8).
} 
The dialogues in the Guanzi are set in the context of deep social and economic change. A ritual order gave way to a time of war and chaos (Graham 1964, p. 29; von Glahn 2016, p. 82). New military and economic forces were unleashed as part of a process of "big fish eating small fish" (Li 2013, p. 182). Several hundred agrarian city states were merged into seven territorial, bureaucratic states (von Glahn 2016, p. 44; 82; Li 2013, p. 182). Institutions gradually developed that laid the foundation for a unified Chinese empire and shaped its future statecraft (Li 2013, p. 182; von Glahn 2016, p. 46). A deep transformation of production occurred in parallel with the emergence of a new political order. Family farms became the basic agricultural production unit (Li 2013, p. 189; von Glahn 2016, p. 46; 82). The iron revolution introduced new production techniques (Wagner \& Needham 2008). Together, these changes brought about a drastic improvement in agricultural productivity, which in turn gave rise to increasing handicraft activities in the households and, ultimately, to an enhanced functional and regional division of labour (Hu 2009, p. 19; von Glahn 2016, p. 65; 82).

This transformation in production propagated a fundamental change in the organization of commerce and created the need for a new form of state market relations. Markets in the Western Zhou Period were under strict, direct government control including price setting (Hu 2009, pp. 7-8). Following the breakdown of the Western Zhou a new urge for free trading of commodities emerged ( $\mathrm{Hu} 2009, \mathrm{p} .19)$. The invention of coinage and the proliferation of currency by the state facilitated long-distance trade. Commerce flourished, and a new class of private merchants became prevalent (von Glahn 2016, p. 46; 64). The rulers of the Warring States turned to this merchant class to assist them in establishing a new form of control over the economy (von Glahn 2016, p. 46). It is in this historical context that some writers of the Guanzi derived their remarkable recommendations on harnessing the newly unleashed market forces by the state. At the core of their program were price regulations based on the light-heavy (轻 重) principles.

The next section introduces the basic theoretical outlook in the Guanzi. Following that introduction, we will turn our attention to the application in concrete policies.

\subsection{The Light-Heavy Principles}

In the context of the fierce interstate competition of the Spring and Autumn Period, "all ducal states had been hankering for the art of "making the state rich and the army powerful"' $(\mathrm{Hu}$ 2009, p. 120). The light-heavy principles were developed to meet these aims of strengthening state and army. They find their most systematic expression in the Guanzi (Chin 2014, p. 31; Hu 2009 , p. 120). Enriching the country is the starting point: "a ruler who is good at ruling the state must first of all enrich his people, then govern them" (Guanzi as in Hu 2009, p. 102). As Rickett (1998, p. 338) explains in his introduction to the Guanzi,

Qing 轻 means "light" and by extension "unimportant," "inconsequential, "or "cheap." As a verb, it means to accord little or no value to something. Zhong 重 means "heavy," and by extension "important," "serious," or "expensive." As a verb, it means to value something. As a compound the two characters usually mean "weight." 
Based on this literary meaning, Ye's (2014, p. 98) translation as "Weighing and Balancing Economic Forces" is apt. From the perspective of qingzhong, all economic phenomena can only be understood relationally; things can be heavy or light only in relation to other things. Heavy commodities are considered essential to production or human well-being, and light commodities are seen as inessential. But precisely what commodity is defined as heavy or light is subject to constant change and reflects the season of the year, production practices, and market dynamics, among other factors. The task of economic policy is to weigh and balance, to use what is found to be heavy in order to offset what is light. Or, in the words of the Guanzi: "To use the thing that is 'heavy' to shoot at that which is 'light', to use the cheap to level down the dear, these are the great advantages that can be drawn from the application of the 'lightheavy' doctrine" (Guanzi as in Hu 2009, p. 127).

Hence, the state should not work against the spontaneous forces inherent in the economy, society, and natural environment; it should instead use these forces to first enrich and then govern the people while generating revenue for the state. State regulation must be based on detailed knowledge of the real conditions and their changes. To this end, the Guanzi recommended extensive empirical surveys and the use of statistics and calculations (Chin 2014, p. 42; Guanzi as in Rickett 1998, pp. 389-95; Hu 2009, pp. 155-7; von Glahn 2016, pp. 7-8). The state was to observe the movements in the market manifested in price changes as well as prevailing fundamental conditions such as population, natural resources, skills, seasonal changes, and regional peculiarities. As far as the prices of specific commodities were concerned, the ruler had to understand the following principles, determining what was "heavy," or dear, and what was "light," or cheap: "When things are plentiful, they will be cheap; when they are scarce, they will be expensive" (Guanzi as in Rickett 1998, p. 384).

In modern language, this principle says that the price of a commodity is determined by its scarcity. But prices were also affected by a second principle: "Goods if concentrated will become 'heavy', but will turn 'light' once they are scattered about" (Guanzi as in Hu 2009, p. 124).

This pointed to the institutional structure of suppliers as one of the determinants of prices. If the goods are in the hands of few (i.e., they are monopolized), they will be expensive. If many suppliers offer identical goods, the goods will be cheap. In other words, scarcity is not simply about the absolute quantity of goods in the market but also about the distribution of these goods across producers. If goods are concentrated in few hands, those in control of supply can generate artificial scarcity to charge higher prices. The Guanzi anticipated the idea of monopoly price markups.

Furthermore, the demand for goods influenced their price: "Goods worth being hoarded will become 'heavy', and conversely [if not worth hoarding] will become 'light'. Goods cornered will be 'heavy', or otherwise will be 'light'” (ibid., p. 124).

This principle suggested that goods that are demanded as a store of value of some sort, rather than to satisfy some immediate need or want, will increase in price when people try to hold onto their wealth in some physical, non-monetary form. When there is a rush on such goods and they are withdrawn from the market, they become scarce and hence expensive. 
Finally, the government's taxation affected the price, according to the Guanzi: "An urgent decree to collect tax in the form of certain goods will make the goods in question 'heavy', but a go-slow decree will make them 'light'” (ibid., p. 124).

With regard to taxation, the writers of the Guanzi saw time as the crucial factor: If people have to pay a certain commodity as tax to the government in a rush, the price will shoot up, but when they have time to collect the required commodities, this will not be the case. In modern language, we call the underlying phenomenon a "demand shock."

All these principles build on the idea that relative value depends on supply and demand. But rather than focusing on the equilibrium between supply and demand, as economists are accustomed to do in modern neoclassical economics, the Guanzi explores reasons for change. The crucial point is that all these price-determining conditions were thought to vary depending on concrete circumstances. Things are not universally "heavy" or "light"; they change their designation depending on the context, which is analysed in ways more dynamic than a simple assessment of some given constellation of supply and demand. Therefore, the Guanzi suggested: "There is no rigid art of the 'light' and 'heavy', but to respond to anything that is showing signs of coming and to take advantage of any tidings heard" (Guanzi as in Hu 2009, pp. 127-8).

As a result, the art of governing depended on being flexible: "The true king takes advantage of the situation, and the sage takes advantage of the principles of change" (ibid., p. 41).

However, it would be a mistake to conclude that the qingzhong principles only knew the movements in the market. Qingzhong economic policies aimed to use the individual pursuit of profit and self-interest to enrich the state while balancing and integrating the economy. When people valued something, it would become "heavy" or in the opposite case "light." Yet social wealth was defined not in terms of the subjective value but in terms of the fundamentals of material well-being. In a vastly agricultural society this was essentially the ability to cultivate the land to its fullest. Labour and land were the ultimate sources of wealth; and because the subsistence of people depended on grain, it was considered the most fundamental commodity in the Guanzi: “A man can't eat without grain, grain can't grow without land, land can't do without man, and man can't get rich without labour" (Guanzi as in Hu 2009, p. 104). Grain, being the centrepiece of wealth, takes the most crucial position in relation to all other commodities and is hence of utmost importance in the qingzhong economic policy. Grain, it is suggested, determines the price of all other commodities, including money:

The price of commodities will rise or fall along with the value of money, and it is grain alone that will determine whether they are expensive or cheap. ... When grain is expensive, all other things are cheap, when grain is cheap, all other things are expensive (Guanzi as in Rickett 1998, p. 367).

This means that the value of money move in opposite directions. The price of grain affects all people in determining the general price level. At the same time, it affects the rural and urban 
populations in different ways. Even before the writing of the Guanzi, Li Kui, the economic advisor to Duke Wen of the Wen State, noticed ${ }^{9}$

If grain ... was very expensive it would injure the people (other than the farmers); while if it was very cheap it would injure the farmers. ... Consequently whether [the price was] very high or very low, the injury was one and the same (Han Shu as in Swann 1950, pp. 139-40, insertions in original). ${ }^{10}$

In the Guanzi, this notion is further developed. The balancing of the grain price becomes the core of the "art of planned fiscal management" (Guanzi as in Rickett 1998, p. 361), an art of government that aims to achieve stability and prosperity for the state, using the principles of qingzhong. This policy of balancing the grain price is the subject of the next section.

\subsection{Balancing the Grain Price}

Besides recognizing grain as the "people's Master of Destiny" (ibid., p. 384; 77), the progression of the seasons is another condition that qingzhong economic policies take as a starting point. We read in the Guanzi that "the climatic changes of the four seasons and the rotation of day and night were objective laws. They could not be decreased if they were oversupplied and could not be increased if undersupplied" (as in Hu 2009, p. 105). From this, the following problem arises. Qingzhong suggests that the price depends on whether something is oversupplied or undersupplied. Depending on the season, grain is oversupplied (harvest) or undersupplied (spring). As a result, the price fluctuates - which is bad both for peasants and for urban consumers. Thus, the ruler faced the question of how to balance the price of grain throughout the year. According to the Guanzi, "states that adhere to the way of a true king act in accordance with the seasons" (ibid. 1998, p. 365). This suggests that, in general, the state must "make use of what is valued to acquire what is not valued and what has been acquired cheaply to ease the price of what has become too expensive" (ibid., pp. 381-2). Furthermore, "when the prince mints coins to establish a money supply, the people all accept them as a medium of exchange" (ibid., p. 380). Hence, the prince can issue money. "Therefore those who are skilled in government manage mediums of exchange in order to control the Masters of Destiny" (ibid., p. 378). The government has a responsibility to stabilize the price of grain in order to stabilize the overall price level and the value of money.

This manifested as government purchase of surplus grain from the peasants in autumn, at harvest time, when it was oversupplied and its price was low - in other words, grain was "light" and money was "heavy." By demanding relatively large amounts, the government drove up the price of grain. It thereby balanced the relative quantities of money and grain in the market, prevented the downward movement of the grain price, and protected the peasants from selling their grain at overly low prices to private merchants. In each locality, the government established public granaries to store the grain. In spring, when the farmers were ploughing and sowing, and in summer, when they were weeding, their grain reserves would run low. The supply of grain on the market was short, and the grain price was high. At that time, the

\footnotetext{
${ }^{9} \mathrm{Hu}(2009)$ suggests that "Li Kui was not only a well-known statesman but also the earliest thinker to emphasize agriculture" (180).

${ }^{10}$ See Rickett (1998, p. 340) for elaborations on this passage.
} 
government used parts of the grain stored away to increase the supply in the market. The government balanced the upshot in the price of grain and protected the peasants from having to buy grain at very high prices from private merchants. ${ }^{11}$

The scheme stabilized both the price for grain and the general price level. First, we have seen that in the Guanzi, the prices of all things depended on that of grain. Second, by participating in the market for grain, the state adjusted the money supply. Since the value of money, like that of all other commodities, was found to depend on its quantity, a change in the money supply would affect its value in relation to all other goods. In other words, it would change the overall price level. ${ }^{12}$ According to the Guanzi, "When grain is cheap, he [the prince] exchanges money for food" (Guanzi as in Rickett 1998, pp. 377-8). In such a situation, money would be "heavy" and would buy a relatively great amount of grain, hence the price level is low. As the state bought a considerable amount of grain, the price of grain rose, but the value of money also fell, and hence a deflationary tendency was balanced. The opposite occurred in spring and summer, when grain was expensive. The state balanced the price of grain in money and the price of money in grain by balancing the quantities of money and grain in circulation. This is how the Guanzi envisioned the government to "manage mediums of exchange in order to control the Masters of Destiny" (Guanzi as in Rickett 1998, pp. 377-8). This was the basic scheme of grain price balancing. Beyond the immediate effects on prices, it had important implications for state revenues, inequality, and famine prevention through countercyclical policies.

First of all, although the state balanced the price movements, it did not aim for complete stability_-"When water is perfectly level, it will not flow" (ibid., p. 308). The price of grain in autumn would still be higher than in spring and summer, but the price difference would be smaller than it had been without the state's participation in the market. As a result of the price difference, the state participation in the grain market generated government revenues. The state did not have to impose any direct taxes: "By taking advantage of government orders to move goods and money back and forth, there is no need to make any demands on the people in the form of special taxes and levies" (ibid., p 392). The rulers of Western Zhou had fixed prices by decree and extracted surpluses from the people by direct taxation. In contrast, the new art of government was to use price fluctuations to enrich the country without undermining the enthusiasm of the peasants. Mastering this new "art of planned fiscal management" was "not something to create resentment among the people or ruin their aspirations" (ibid., p. 362).

\footnotetext{
${ }^{11}$ The basic principles of this policy of grain price stabilization are repeated in almost all the qingzhong dialogues in the Guanzi. This is a summary of the basic principles by the present authors. Variations on this scheme include (1) the use of loans to the peasants paid out in spring in grain and pegged to the high money price to be paid back when the price of grain is low in the fall (Guanzi as in Rickett 1998, pp.377-80; 343-4), as well as (2) the state purchase of clothes when they are cheap because grain is expensive; they are then sold by the state when clothes become expensive in the fall, at a time when grain is cheap (Guanzi as in Rickett 1998, p.362; 367; 384; 391). Similar, yet less encompassing, policy proposals had previously been put forward by Fan Li (Chen 1911b, p. 568; Hu 2009, pp. 35-41; von Glahn 2016, p. 64) and Li Kui (Chen 1911b, p. 568; Hu 2009, pp. 179-184; Li 2013, p. 190; Spengler 1964, p. 228; von Glahn 2016, p. 55).

${ }^{12}$ In the light of this insight, the Guanzi is found to be one of the earliest articulations of the quantity theory of money (Hu 2009, p. 131; Nolan 2004, p. 129; Rickett 1998, p. 4). If we consider the suggestions for countercyclical government spending, discussed later in this section and the elaborations on hoarding, together with the grouping of different types of money according to their liquidity, a question for further research emerges: Might we find not only the earliest articulation of the quantity theory of money in the Guanzi but also, thanks to its focus on transitional effects, a precursor to the breaking of a pure quantity theory as in Keynes's (1936) General Theory?
} 
Instead of taking away from the people by command, the state sold grain to the people when they needed it, thereby lowering the price, and bought grain from the people when they had it to sell, thereby raising the price. Instead of being subjected to direct taxation, the people would experience the state as a benevolent government. In sum, this approach would create "stability similar to placing a square object on the ground" (ibid., p. 367).

Furthermore, the policy of balancing grain prices prevented great inequalities without making all people equal. ${ }^{13}$ At the time, a class of private merchants was rising. In fact, the government learned the techniques of market participation from the merchants. As prices were not directly controlled by the state any longer, it became apparent that "[a]s the harvest is bad or good, grain will be expensive or cheap" (Guanzi as in Rickett 1998, p. 379). If the government did not utilize these price movements to generate public profit, private merchants would do so: "if the prince is not able to control the situation, it will lead to large-scale traders roaming the markets and taking advantage of the people's lack of things to increase their capital a hundredfold" (ibid.). ${ }^{14}$

The profit motive was not condemned morally in the Guanzi but faced as a reality: "it is the nature of men that whenever they see profit, they cannot help chasing after it" (Guanzi as in Rickett 1998, p. 219). The task of the ruler was hence not to appeal to the morality of the people but to use the prevailing interests and "regulate the people's profits" (ibid., p. 379). In order to do this, the state had to "maintain control over policies affecting prices" (ibid., p. 366). Land reform was not enough to prevent inequalities: "Even though the land may have been divided equally, the strong will be able to gain control of it; even though wealth has been distributed equally, the clever will be able to accumulate it" (ibid., p. 379). If the government failed to balance the grain price, "it will only result in the people below enslaving each other." When such "great inequality exists between rich and poor," the "multitude is not well governed" (ibid., p. 380). Hence, "[s]hould the prince fail to maintain control over policies affecting prices ... the economic policy of the state becomes meaningless" (ibid., p. 366).

Finally, and most essentially, the participation in the grain market allowed the state to accumulate grain in each locality and protect people from the consequences of natural disasters. An elaborate system of famine prevention worked hand in hand with a countercyclical fiscal policy. The government's task was to protect the people from the changes of the seasons, climate, and the market and to ensure their access to daily necessities at all times. The state employed the people when the seasons did not require them to work in the field. In this way, the state prevented the source of wealth from drying up. The ruler was to practice frugality in

\footnotetext{
${ }^{13} \mathrm{Or}$, as $\mathrm{Hu}$ (2009) puts it, "The writer of Guanzi asserted that this inequality between rich and poor was an objective social reality, but his solution to the problem was merely to mitigate the antagonism, not to wipe it out entirely" (111).

${ }^{14}$ Such great inequalities are, for example, reported in the Han Shu to have occurred in the period 246-207 BCE. After the selling and buying of land was allowed, some individuals became very rich and brought both land and natural resources under their control. The poor had to cultivate the land of the rich and "had to give five-tenths [of the crop] for rent (shui)" (Han Shu as in Swann, 1950, 182, insertion in original). "In profligacy and dissipation they [the rich] overrode government institutions; and they overstepped extravagance in order to outdo one another" (Han Shu as in Swann 1950, p. 181). "Consequently the poor people wore at all times [garments in quality fit only] to be covering for cattle and horses. They ate, moreover food [of a standard suitable only] for feeding dogs and swine. ... The people, brought to grief, had no means of livelihood; and they became thieves and robbers" (Han Shu as in Swann 1950, p. 182, insertion in original).
} 
normal times so as not to divert too much of the people's time from the fundamental occupation of agriculture. However, "prodigality should be adopted in a special situation" (Hu 2009, p. 116). If the people lost the foundation of their livelihood and could not work their land because of natural disasters, the state should offer them employment. At such times, the state should also encourage the rich to create work-for example, by encouraging them to have lavish funerals (Guanzi as in Rickett 1998, p. 319). In sum, the Guanzi holds that those "who are good at ruling a state simply depend upon the situation to relax or intensify their demands" (ibid., p. $415) .{ }^{15}$

\section{Conclusion}

We have seen that the Guanzi articulated distinct principles of government balancing of prices, market creation, famine prevention, and monopoly control, which were developed in a period when “a new order emerged from great chaos" (拔乱反正). These policies aimed to protect the peasant majority from violent fluctuation, cycles, and speculation in the context of the recently unleashed market powers and to increase commercialization of society while enriching the state. Rather than working against powerful economic trends, this approach to economic policy suggested that the state should unleash and harness market forces in order to promote its wealth.

In the Guanzi's conception the state is both a market creator and stabilizer. There is no clear separation of the bureaucracy and a private market. Rather the market economy is created and regulate through the state's direct commercial participation. The market without the state is conceptualized as inherently unstable which becomes apparent in the violent price fluctuations and the threat of famine absent state participation. This means that from the perspective of the Guanzi the nature of the market without the state is to not be in a position of rest or equilibrium. As such there is no natural, uniform price that sellers could adhere to. The stable price only emerges as a result of the balancing by the state. But the Guanzi also insists that the act of balancing is never perfect and always involves imbalance. This stable price is an empirically determined price that emerges through the act of balancing the market. It cannot be theoretically derived or fixed by state order.

Conceptualizing turbulences as an inherent feature of the market when left to its own devices is a fundamentally different starting point from that of ancient Greek philosophers like Plato and Aristotle. Coming to the question of price determination from the angle of moral philosophy, they foreground the right behaviour on the part of the individual not the structural features of the market. This leads to an emphasis on a moral obligation to charge a fair price that evolves in Roman law into the state's right to police and punish those who overcharge their customers. This is in sharp contrast to the Guanzi's insistence on fluctuations of prices as ingrained in the dynamics of the market and the structures of the economy. Movements in prices in the Guanzi do not emerge from the individuals' wrong doings but from the normal and

\footnotetext{
15 This proposal for a countercyclical policy of government spending clearly anticipates, by 2000 years, Mandeville's (1970 [1724]) Fable of the Bees, Malthus's letters to Ricardo (as in Keynes 1936, pp. 362-3), and Keynes' theory of effective demand. In light of Keynes's 1912 review of Chen Huan-Chang (1911b), which contains a treatment of grain price policies (568-85), the question emerges whether Keynes might in fact have been inspired by ancient Chinese economic thinking.
} 
legitimate pursuit of self-interest. Therefore, prices can also not be stabilized by punishing individuals or by appealing to their moral obligations. Instead, price stabilization from the Guanzi's perspective requires for the state to balance the structural forces at play. We might want to think of the Guanzi as a precursor to monetary macroeconomics. In contrast, Platon and Aristotle path the way for the Italian Scholastics' inquiry into the right price that prefigures the value theory of the classical economists.

Here, this comparative exploration of the Guanzi must remain preliminary. To comprehensively appreciate the differences and commonalities between ancient Greek, Roman and Chinese thought a much larger research project is required. I hope this piece inspires some readers to move from Schumpeter's dismissal of Chinese contributions to curiosity for this tradition of thought. 


\section{References}

Baldwin, John W.: The Medieval Theories of the Just Price: Romanists, Canonists, and Theologians in the Twelfth and Thirteenth Centuries. In: Transactions of the American Philosophical Society, 49(4), pp. 1-92, 1959.

Chang, James L. Y.: History of Chinese Economic Thought: Overview and Recent Works. In: History of Political Economy, 19(3), 481-499, 1987.

Chen, Huan-Chang: The Economic Principles of Confucius and His School, Vol. I. New York: Columbia University Press, 1911a.

Chen, Huan-Chang: The Economic Principles of Confucius and His School, Volume II. New York: Columbia University Press, 1911 b.

Chin, Tamara: Savage Exchange: Han Imperialism, Chinese Literary Style, and the Economic Imagination. Cambridge, Massachusetts: Harvard University Asia Center, 2014.

Graham, A.: The Place of Reason in the Chinese philosophical tradition. In: R. Dawson (ed.): The Legacy of China. Oxford: Oxford University Press, pp. 28-56, 1964.

Hu, Jichuang: A Concise History of Chinese Economic Thought. Beijing: Foreign Language Press, 2009.

Keynes, John Maynard: Review: The Economic Principles of Confucius and his School by Chen Huan-Chang. In: The Economic Journal, 22(88), pp. 584-588, 1912.

Keynes, John Maynard: The General Theory of Employment, Interest and Money. New York: Harcourt, Brace and World, 1936.

Li, Feng: Early China: A Social and Cultural History. Cambridge: Cambridge University Press, 2013.

Lin, Cheng; Peach, Terry; Fang, Wang (eds.): The History of Ancient Chinese Economic Thought. Abingdon: Routledge, 2014.

Lin, Cheng; Peach, Terry; Fang, Wang (eds.): The Political Economy of the Han Dynasty and Its Legacy. Abingdon: Routledge, 2019.

Mandeville, Bernard: The Fable of the Bees. London: Penguin Books, 1970.

Milburn, Olivia: The Book of the Young Master of Accountancy: An Ancient Chinese Economics Text. In: Journal of the Economic and Social History of the Orient, 50(1), pp. 19-40, 2007.

Nolan, Peter: China at the Crossroads. Cambridge: Polity Press, 2004.

Pines, Yuri: Envisioning Eternal Empire: Chinese Political Thought of the Warring States Era. Honolulu: University of Hawai'i Press, 2009.

Pines, Yuri: Legalism in Chinese Philosophy. In: Stanford Encyclopedia of Philosophy [online: https://plato.stanford.edu/entries/chinese-legalism/], 2018.

Rickett, W. Allyn: Kuan tzu 管子. In: M. Loewe (ed.): Early Chinese Texts: A Bibliographical Guide. New Haven: Birdtrack Press, pp. 244-251, 1993. 
Rickett, W. Allyn: Guanzi: Political, Economic and Philosophical Essays from Early China. Vol. II. Princeton, N.J.: Princeton University Press, 1998.

Schefold, Bertram: Platon und Aristoteles (418/427-348/347; 384-322). In: J. Starbatty (ed.): Klassiker des Ökonomischen Denkens: Erster Band von Platon bis John Stuart Mill. München: C.H. Beck, pp. 19-55, 2008.

Spengler, Joseph: Ssu-Ma Ch'ien, Unsuccessful Exponent of Laissez Faire. In: Southern Economic Journal, 30(3), pp. 223-243, 1964.

Swann, Nancy Lee: Food and Money in Ancient China: The Earliest Economic History of China to A.D. 25 (Han Shu 24). Princeton, N.J.: Princeton University Press, 1950.

von Glahn, Richard: The Economic History of China: From Antiquity to the Nineteenth Century. Cambridge: Cambridge University Press, 2016.

Wagner, D. B.; Needham, J.: Science and Civilisation in China. Vol. 5. Chemistry and Chemical Technology. Party 11. Ferrous Metallurgy. Cambridge: Cambridge University Press, 2008 .

Weber, Isabella M.: How China Escaped Shock Therapy: The Market Reform Debate. Abingdon: Routledge, 2021.

Witzel, Morgen: Introduction. In: The Economic Principles of Confucius and His School, Vol. I. Bristol: Thoemmes Press, pp. v-xv, 2002.

Ye, Shichang: On Guanzi Qing Zhong. In: Lin, Cheng; Peach, Terry; Fang, Wang (eds.): The History of Ancient Chinese Economic Thought (pp. 98-106). Abingdon: Routledge, 2014. 